Research Article

\title{
Detection of RUNXI-RUNXITI Fusion Gene in AML Patients by FISH Technique in Iraq
}

\author{
Dahlia N AL-Saidi', Bassam M Hameed ${ }^{2}$, Khaleed ] Khaleel ${ }^{3}$ \\ ${ }^{1}$ Department of Laboratory Medical Techniques, AL-Nisour University College, Iraq. \\ ${ }^{2}$ Department of Pathology \& Forensic Medicine, College of Medicine, Al-Nahrain University, Iraq. \\ 3 Department of Medical genetics, Institute Iraqi Center for Cancer and Medical Genetics Research, Mustansirya University, Iraq. \\ DOI: https://doi.org/10.24321/0019.5138.202174
}

\section{I $\quad \mathbf{N} \quad \mathbf{F} \quad \mathbf{O}$}

\section{Corresponding Author:}

Dahlia N AL-Saidi, Department of Laboratory Medical Techniques, AL-Nisour University College, Iraq.

E-mail Id:

d.nayeef@gmail.com

Orcid Id:

https://orcid.org/0000-0001-8141-638X

How to cite this article:

AL-Saidi DN, Hameed BM, Khaleel KJ. Detection of RUNX1-RUNX1T1 Fusion Gene in AML Patients by FISH Technique in Iraq. J Commun Dis. 2021;53(4):54-60.

Date of Submission: 2021-09-25

Date of Acceptance: 2021-10-15

\section{$\begin{array}{llllllll}\mathbf{A} & \mathbf{B} & \mathbf{S} & \mathbf{T} & \mathbf{R} & \mathbf{A} & \mathbf{C} & \mathbf{T}\end{array}$}

Background: AML with $\mathrm{t}(8 ; 21)(\mathrm{q} 22 ; \mathrm{q} 22.1)$ is a balanced translocation that results in the fusion of RUNX1 and RUNX1T1. The translocation product is located on derivative chromosome 8 . It has characteristic morphologic and immunophenotypic features and is linked with good prognosis. $t(8 ; 21)(q 22 ; q 22.1) A M L$ is diagnostic of $A M L$ regardless of blast count.

Objectives: To detect the RUNX1-RUNX1T1 fusion gene) in patients with AML by FISH technique and to investigate the relation between this chromosomal abnormality and the immunophenotypic markers CD117, CMPO, CD34, CD13, CD64 and CD33, clinical features and haematological parameters ( $\mathrm{Hb}, \mathrm{WBC}$, blast percentage and platelets).

Materials ad Methods: Fifty patients with de novo AML were selected sequentially from Baghdad teaching hospital in medical city from June 2020 till April 2021. History was taken and data were collected for each patient using a questionnaire form that included: name, age, sex, symptoms and physical signs. The data of haematological parameters and CD markers expression were collected from the patients' diagnostic reports.

Results: The RUNX1/RUNX1T1 fusion gene expression was positive in 4 patients representing $8 \%$ whereas 46 patients representing $92 \%$ of the samples had negative gene expression. Among the 4 positive AML patients for RUNX1/RUNX1T1 fusion gene expression, M2FAB subtype was revealed in all the cases. All the positive cases expressed CD117 and CD34 markers, while it was noted that 3 out of 4 positive cases were having CMPO and CD13 markers and one positive case expressed CD33 and CD64.

Conclusion: It's shown that RUNX1-RUNX1T1 fusion gene frequency in AML Iraqi patients is similar to international reports.

Keywords: Acute Myeloid, Leukaemia, Translocation, FISH, t(8; 21), RUNX1-RUNX1T1 


\section{Introduction}

Acute Myeloid Leukaemia (AML) with recurrent genetic abnormalities is connected to distinctive clinicopathological features having prognostic significance and is considered the most powerful predictors of treatment outcome. $t(8 ; 21)$ is considered as the commonest specific translocation available. ${ }^{1}$ In this type of translocation, there is neutrophil lineage maturation. There are large myoblasts with abundant basophilic cytoplasm that contain azurophilic granules in the peripheral blood as well as in the bone marrow. RUNX1-RUNX1T1 fusion gene induces cell differentiation, renewal capacity and proliferation. It also inhibits the core-binding factor that plays a key role in early haematopoiesis. It has been found that RUNX1- RUNX1T1 and core-binding factor targeting are not enough to induce leukaemia. More additional mutations are needed to trigger leukaemogenesis. ${ }^{2}$

Diagnosis of this type of recurrent translocation needs either Fluorescence In Situ Hybridization (FISH) or Polymerase Chain Reaction (PCR) and both techniques are still not used as routine diagnostic practice in Iraq. Diagnosis depends only on FAB classifications based on morphology in Iraq. In this study, we studied the frequency of RUNX1-RUNX1T1 fusion gene in a sample of AML Iraqi patients by using the FISH technique as an attempt to clear up the exact role of this genetic aberration in the AML subtype.

\section{Materials and Methods}

This cross-sectional study was conducted from June 2020 till April 2021 and was approved by the institutional review board of medical college/ Al-Nahrain University. Work was done in the post graduate lab of Pathology and Forensic Medicine Department and Medical Researches Unit in AlNahrain College of Medicine. Informed consent was taken from each participating patient. Data were collected for each patient using a questionnaire that included: name, age, sex, main symptoms, and physical signs. The data regarding haematological parameters and CD markers expression were collected from the patients' diagnostic reports. Fifty patients with de novo AML were selected sequentially from Baghdad teaching hospital in the medical city.

Patients' criteria of inclusion were: a new diagnosis with AML by immunophenotype with an age of more than or equal to 18 years old. Also, patients were not known to have any other malignant disease or have taken any chemotherapy. The diagnosis depended on immunophenotyping as well as morphology of peripheral blood and bone marrow samples by haematopathologists in the laboratories. Sodium heparinized peripheral blood sample of $3 \mathrm{ml}$ was collected and labelled with the patient's age, name, and date of collection. After centrifugation, the specimens were stored as a fixed pellet at $4^{\circ} \mathrm{C}$ till the start of FISH studies. FISH was done by using a dual colour, directly labelled $R U N X 1$ / RUNX1T1 fusion probe to reveal the signal of fusion gene in cells containing $t(8 ; 21)$. In cells with $t(8 ; 21)$, the yellow fusion signal representing $R U N X 1-R U N X 1 T 1$ includes a DNA sequence that hybridizes at (q22; q22.1) as shown in Figure 3.

Statistical analysis was done using Microsoft Excel program and SPSS. P-value < 0.05 was intended to be statistically significant.

\section{Results}

RUNX1/RUNX1T1 fusion gene expression was positive in 4 patients representing $8 \%$ whereas 46 patients representing $92 \%$ had negative gene expression, as shown in Figure 1. Regarding gender, there were 3 male patients who were positive $75 \%$, while in the female group of patients, 1 patient $25 \%$ was positive. The mean age of positive patients for RUNX1/RUNX1T1 fusion gene expression was 52.75 years, whereas, for the negative fusion gene expression group of patients, it was 57.61 years $(P=0.54)$. Table (1).

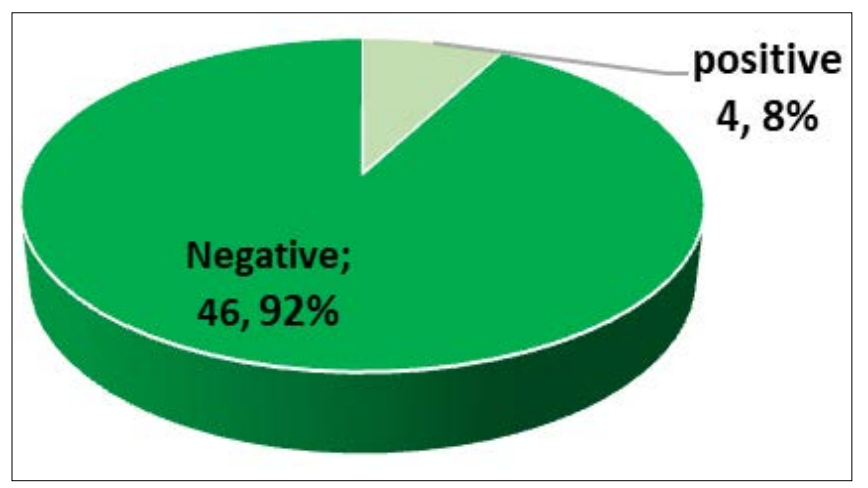

Figure I.t(8;2I) Fusion Gene Expression of AML Cases involved in Study

Four patients came at the time of initial diagnosis. Symptoms at the time of presentation included weight loss, recurrent infection, easy bruising, and fatigue. Regarding the haematological parameters, the mean value of WBC count in patients with positive expression for RUNX1/ RUNX1T1 fusion gene was $38.25 \times 10^{\circ} / \mathrm{L}$, whereas it was $40.7510^{9} / \mathrm{L}(\mathrm{p}=0.70)$ in the negative group. The mean value of $\mathrm{Hb}$ in the positive group was $9.6 \mathrm{~g} / \mathrm{dL}$. On the other hand, it was $8.6 \mathrm{~g} / \mathrm{dL}$ in the negative group $(P=0.39)$. The mean value of platelet count in RUNX1/RUNX1T1 positive gene expression patients was $37.25 \times 10^{9} / \mathrm{L}$, while it was $52.48 \times 10^{9} / \mathrm{L}(P=0.70)$ in the gene expression negative patients. Bone marrow blast cells mean value percentage in the fusion gene expression positive group was $49.25 \%$. On the other hand, it was $52.83 \%(P=0.67)$ in the gene expression negative group as shown in Table 1. 
Table I.Comparison of Parameters according to RUNXI/RUNXITI Fusion Gene Expression in AML Patients

\begin{tabular}{|c|c|c|c|}
\hline & $\begin{array}{c}\text { Positive N 4 } \\
\text { (Mean } \pm \text { SD) }\end{array}$ & $\begin{array}{c}\text { Negative N 46 } \\
\text { (Mean } \pm \text { SD) }\end{array}$ & P-value \\
\hline Age $($ year) & $52.75 \pm 16.3$ & $57.61 \pm 15.1$ & 0.54 \\
\hline $\mathrm{Hb}(\mathrm{g} / \mathrm{dL})$ & $9.6 \pm 2.72$ & $8.63 \pm 2.1$ & 0.39 \\
\hline $\mathrm{WBC}$ count $\left(* 10^{9} / \mathrm{L}\right)$ & $38.25 \pm 15.8$ & $40.75 \pm 12.5$ & 0.70 \\
\hline Blast $(\%)$ & $49.25 \pm 18.46$ & $52.83 \pm 116.16$ & 0.67 \\
\hline Platelet count $\left(* 10^{\circ} / \mathrm{L}\right)$ & $37.25 \pm 9.8$ & $52.48 \pm 19.1$ & 0.12 \\
\hline
\end{tabular}

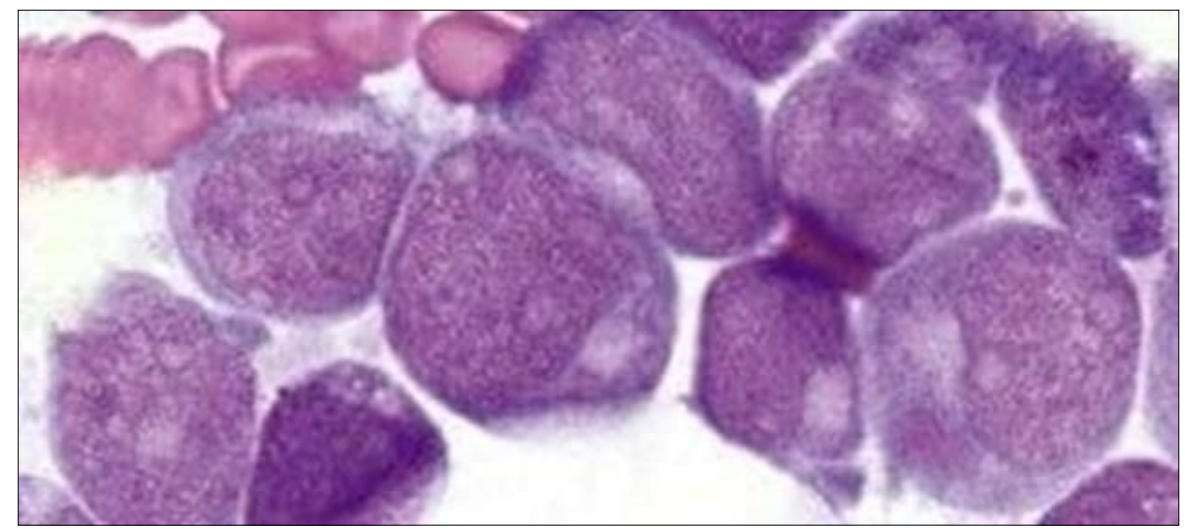

Figure 2.(Case 2) t(8;2I)(q22;q22q22) AML. Smear of Bone Marrow Aspirate showing Auer Rods in Blasts. Granulocytes with Pink Coloured Granules are seen in the Background (Wright-Giemsa stain $\times 1,000$ )

Table 2.Morphological, Immunophenotypic and FISH Diagnostic Findings

\begin{tabular}{|c|c|c|c|c|}
\hline Case No. & Blast Morphological Features & FAB Type & Immunophenotype & FISH \\
\hline 1. & $\begin{array}{r}\text { Pink granules, basophilic cytoplasm, no } \\
\text { Auer rods }\end{array}$ & $\mathrm{M} 2$ & $\begin{array}{c}\mathrm{CD} 13-, \mathrm{CD} 64+, \mathrm{CD} 33+, \mathrm{CD} 34+, \\
\mathrm{CD} 117+, \mathrm{MPO}+\end{array}$ & + \\
\hline 2. & $\begin{array}{r}\text { Pink granules, basophilic cytoplasm, } \\
\text { Auer rods }\end{array}$ & $\mathrm{M} 2$ & $\begin{array}{c}\mathrm{CD} 13+, \mathrm{CD} 64-, \mathrm{CD} 33-, \mathrm{CD} 34+, \\
\mathrm{CD} 117+, \mathrm{MPO}+\end{array}$ \\
\hline 3. & $\begin{array}{r}\text { Pink granules, basophilic cytoplasm, no } \\
\text { Auer rods }\end{array}$ & $\mathrm{M} 2$ & $\begin{array}{c}\mathrm{CD} 13+, \mathrm{CD} 64-, \mathrm{CD} 33-, \mathrm{CD} 34+, \\
\mathrm{CD} 117+, \mathrm{MPO}+\end{array}$ \\
\hline 4. & $\begin{array}{r}\text { Pink granules, basophilic cytoplasm, } \\
\text { Auer rods }\end{array}$ & $\mathrm{M} 2$ & $\begin{array}{c}\mathrm{CD} 13+, \mathrm{CD} 64-, \mathrm{CD} 33-, \mathrm{CD} 34+, \\
\mathrm{CD} 117+, \mathrm{MPO}-\end{array}$ \\
\hline
\end{tabular}

Summary of the immunophenotypic and morphologic findings is available in Table 2. Bone marrow aspirate smears displayed blasts with basophilic cytoplasm and salmon pink granules in all the cases. Long Auer rods with large granules were seen in case no. 2 and 4 (Figure 2). Cellularity of 40\%$90 \%$ is shown in the bone marrow biopsy samples with a remarkable increase in the immature myeloid elements.

The flow cytometry analysis of immunophenotype displayed that blasts of all cases are expressing CD117 and CD34. Myeloperoxidase and CD13 were positive in $75 \%$ of the positive cases for $R U N X 1 / R U N X 1 T 1$ fusion gene expression, while CD33 and CD64 markers were expressed in case 1.

FISH analysis was performed on interphase nuclei revealing two RUNX1T1 signals, one signal on the normal while the other one on the abnormal chromosome 8, two RUNX1 signals, one on the normal and the other one on the abnormal chromosome 21, with a single RUNX1-RUNX1T1 fusion signal in 60 of 100 nuclei examined (Figures 3, 4, and 5). 


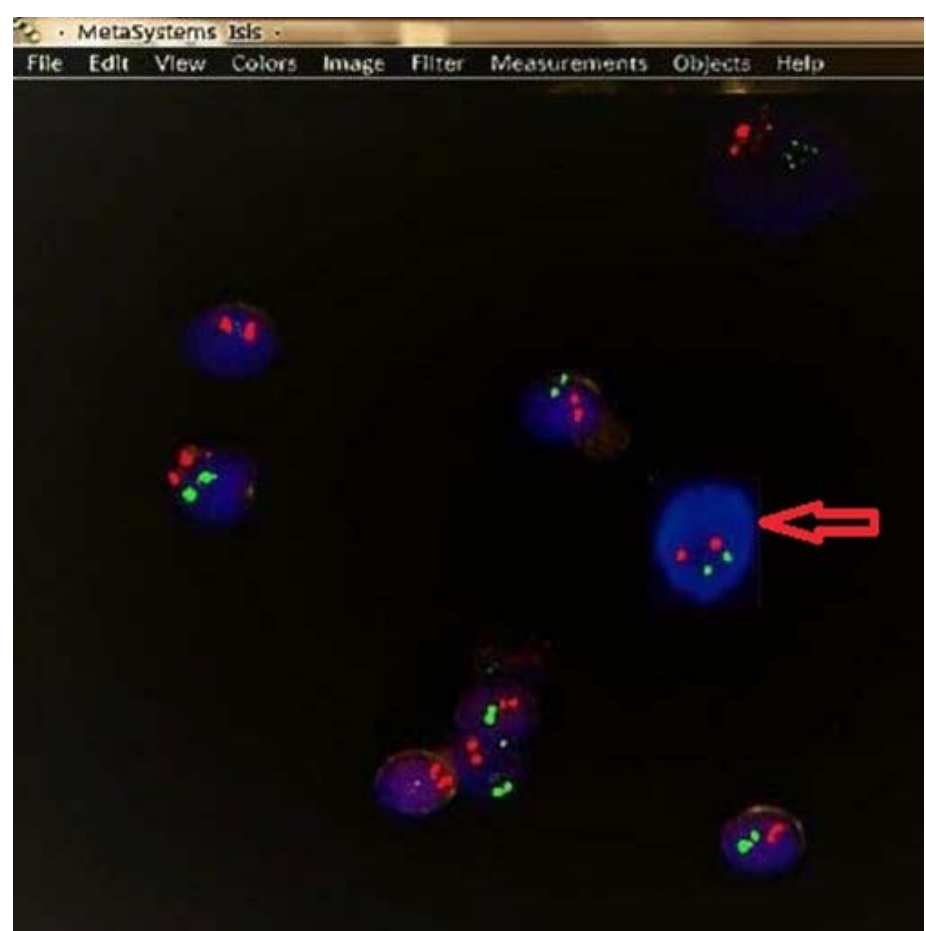

Figure 3.FISH Analysis with the LSI RUNXI/RUNXITI Dual Colour Fusion Translocation Probe on a Peripheral Blood Cell Sample, showing Leukaemic Cells without Fusion Gene Expression. It shows Two Green Signals representing RUNXITI and Two Orange Signals representing RUNXI (Red Arrow)

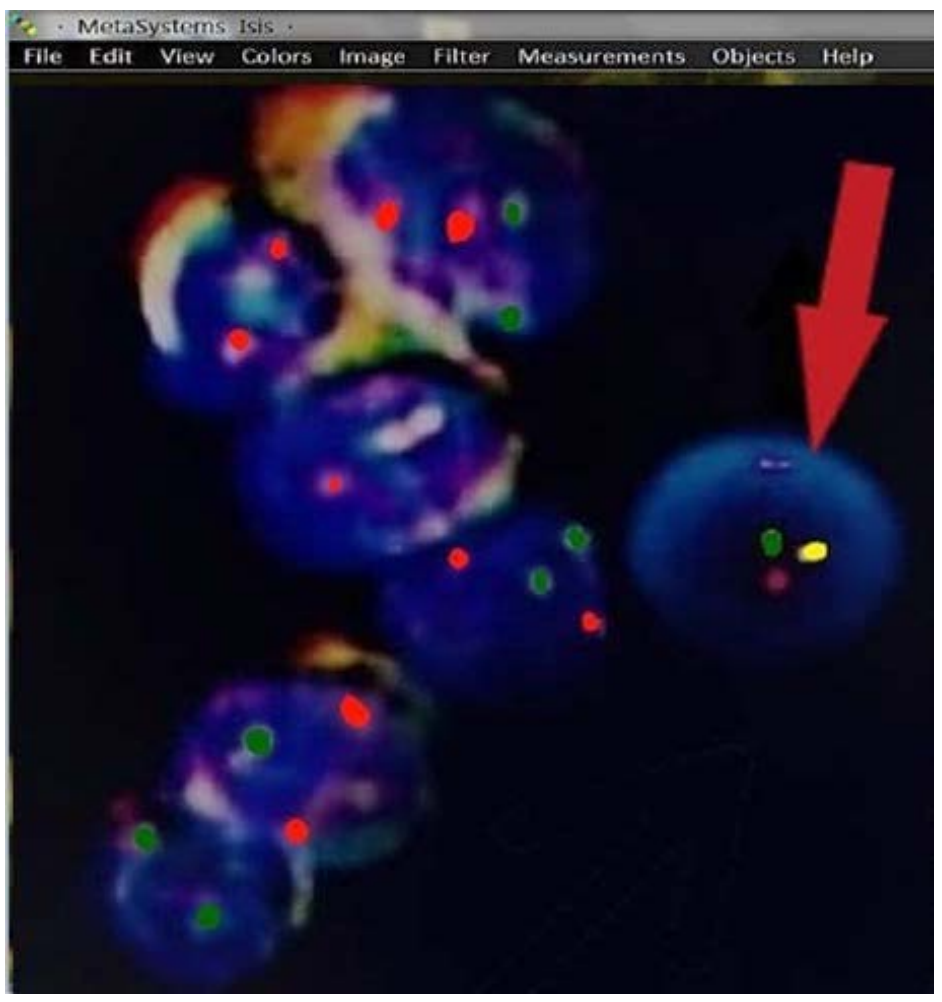

Figure 4.FISH Analysis using LSI Dual/ Colour Probe for Interphase Detection of Gene Fusion, showing Leukaemic cells where the Probe with the Orange-label spans the Breakpoint at 2lq22.I RUNXI and the Probe with the Green-label spans the Breakpoint at 8q21.3-22.I RUNXITI. The translocation (8;2I) results in RUNXI- RUNXITI Fusion on the Derivative Chromosome 8 (Yellow Signal marked by Red Arrow). To simplify its identification, Chromosomes are Counterstained by DAPI on power 60X 


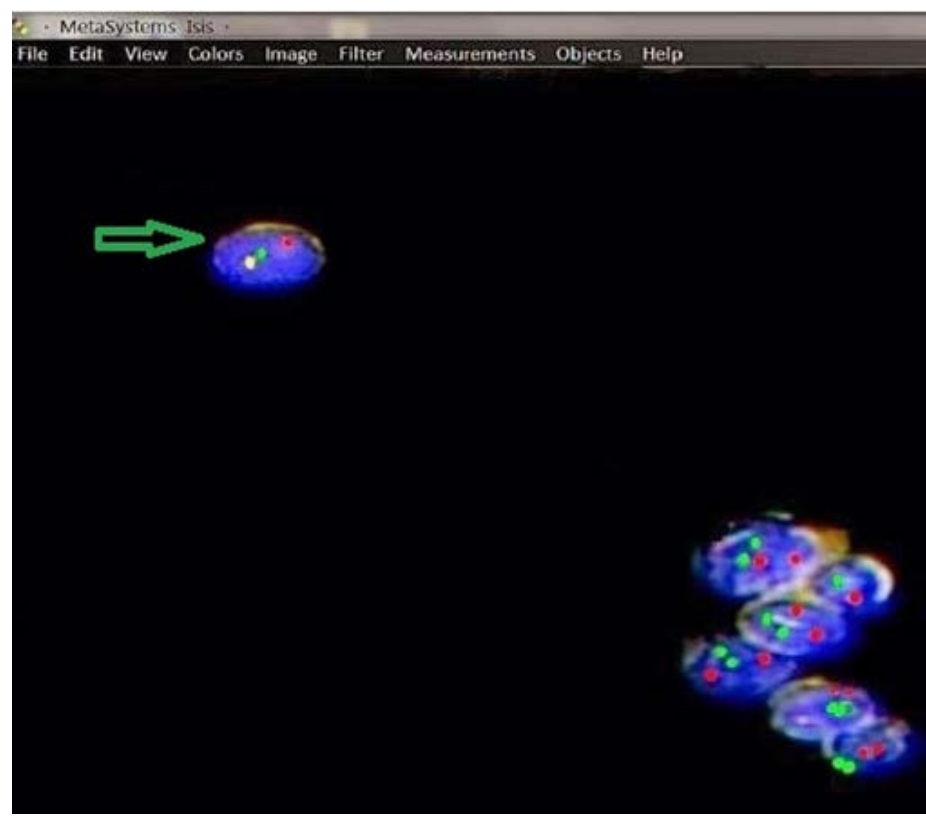

a

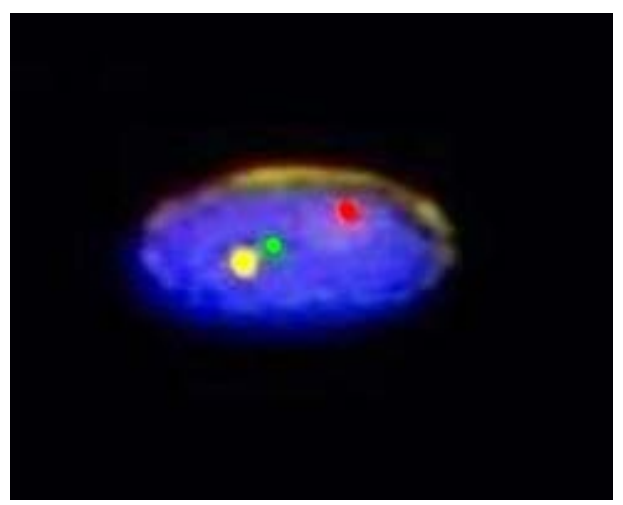

b

Figure 5.(a) FISH Analysis using LSI RUNXI/RUNXITI Dual Colour Fusion Translocation Probe for Interphase Detection of Gene Fusion, showing Leukaemic Cells without Fusion Gene Expression, Two Green Signals representing RUNXITI and Two Orange Signals representing RUNXI. The Yellow Signal indicated by the Green Arrow represents Fusion Gene RUNXI/RUNXITI (b). Zoomed in Image of the Leukaemic Cell with Yellow Signal representing Fusion Gene RUNXI/RUNXITI

\section{Discussion}

$t(8 ; 21)(q 22 ; q 22) A M L$ is realised as a specific type of $A M L$ according to the WHO classification. ${ }^{3}$ It is more frequent in younger patients and is linked to a favourable outcome. ${ }^{4}$ The leukaemic cells have distinctive morphologic features that include pink coloured granules of the cytoplasm with long Auer rods. Most of the cases usually are within AML-M2 category of FAB classification.

RUNX1/RUNX1T1 fusion gene was detected in 4 out of 50 patients $(8 \%)$ by using FISH technique. This result is close to a study in Iraq that reviewed RUNX1/RUNX1T1 mutation among 134 patients with AML by using filter paper cards in 2014 and the result was $14.2 \% .^{5}$ On the other hand, a study in Egypt involving 100 patients revealed that RUNX1/
$R U N X 1 T 1$ fusion gene is present in $45.7 \%$ of the patients by using a different technique. ${ }^{6}$ Here, the frequency of occurrence of $R U N X 1 / R U N X 1 T 1$ transcript is higher than the one observed in the current study. This difference may be due to diversity in age group and population structure involved in that study in addition to the difference in samples' size and the technique used. On an international level, the result of the current study goes with a study that took place in Germany. It showed that $R U N X 1 / R U N X 1 T 1$ is present in $6 \%$ out of 916 patients detected by using PCR. ${ }^{7}$

According to the morphology, all the cases showed morphologic features of the classical $t(8 ; 21)(q 22 ; q 22)$ $A M L$, as well as classified as $A M L-M 2$ according to $F A B$ criteria. The mean age of the positive expression group 
was 52.7 years which is lower than the negative expression group that was 57.6 years. Age distribution of the two groups was statistically not significant $(P=0.54)$. The result mentioned above does not go with other data available. ${ }^{5,6}$ The discrepancy in results may be attributed to small sample size and difference in population structure. Regarding gender, the ratio of males to females in $R U N X 1 / R U N X 1 T 1$ positive group was 3:1. The current result agrees with other data..$^{5,8,9}$

Among the 4 positive AML patients for $R U N X 1 / R U N X 1 T 1$ fusion gene expression, M2 FAB subtype was revealed in all the cases $(100 \%)$. The result in the current study is in agreement with that of other studies. ${ }^{7,10}$

The commonest sign and symptom was pallor in both positive and negative groups for $R U N X 1 / R U N X 1 T 1$ fusion gene expression, followed by fever also in both groups. Lethargy and bleeding percentages in the positive group were higher than in the negative group. Less frequent signs and symptoms were weight loss, hepatosplenomegaly, and LAP which were higher in the positive group. These results are similar to that of other studies. ${ }^{11}$ On the other hand, another study available showed that fever, weakness, and body pain were more common features. ${ }^{10}$

About the haematological parameters, the mean value of WBC in a positive group is almost the same as in a negative group. There was no significant difference between positive and negative fusion gene expression groups $(P=0.70)$ Table 1. In another study, the mean of WBC was close to that obtained by the current study. ${ }^{12}$ In the current study, the mean $\mathrm{Hb}$ level in the positive group was close to that seen in the negative group, statistically not significant. This agrees with other study data which showed that all cases presented with anaemia. ${ }^{13}$ The mean level of platelets in the positive group was much lower than the mean level in the negative group and it was statistically not significant. This result goes with another study which showed that all cases presented with thrombocytopenia. ${ }^{13}$ Regarding the BM blasts, the mean value in a positive expression fusion gene group was lower than the mean level in a negative group and it's statistically not significant. This result agrees with another international study which shows a similar result. ${ }^{13}$

All the positive cases of RUNX1/RUNX1T1 fusion gene expression expressed CD117 and CD34 markers (100\%). This is in agreement with another study. ${ }^{14}$ However, it was noted that 3 out of 4 cases with positive RUNX1/RUNX1T1 fusion gene expression had CMPO and CD13 markers (75\%) and one case expressed CD33 and CD64 (25\%). Studies described a more favourable prognosis to cases in which myoblasts demonstrate co-expression of cMPO, CD33, and CD117. ${ }^{14,15}$

\section{Conclusion}

Our work showed that RUNX1-RUNX1T1 fusion gene frequency in AML Iraqi patients is similar to international reports, with a similar morphological and immunophenotypic pattern.

\section{Source of Funding}

This work was carried out by AL-Nisour University College and was supported by the Medical researches unit in AlNahrain College of medicine, Baghdad.

\section{Conflict of Interest: None \\ References}

1. Al-Harbi K, Aljurf M, Mohty M, Almonhareb F, Ahmed SO. An update on the molecular pathogenesis and potential therapeutic targeting of $A M L$ with $\mathrm{t}(8 ; 21)(\mathrm{q} 22 ; \mathrm{q} 22.1) ; R U N X 1-R U N X 1 T 1$.Blood Adv. 2020;4(1):229-38. [PubMed] [Google Scholar]

2. Kuchenbauer F, Schnittger S, Look T, Gilliland G, Tenen D, Haferlach T, Hiddemann W, Buske C, Schoch C. Identification of additional cytogenetic and molecular genetic abnormalities in acute myeloid leukaemia with t(8;21)/AML1-ETO. Br J Haematol. 2006;134:616-19. [PubMed] [Google Scholar]

3. Arber DA, Brunning RD, Le Beau MM, Falini $B$, Vardiman JW, Porwit A, Thiele J, Foucar K, Dohner H, Bloomfield $C D$. Acute myeloid leukemia with recurrent genetic abnormalities. In: Jaffe ES, Harris NL, Stein $\mathrm{H}$, Vardiman JW, editors. World Health Organization Classification of Tumours: Pathology and Genetics of Tumours of Haematopoietic and Lymphoid Tissues. Lyon, France:IARC Press; 2001:81-2.

4. Steven H. Acute myeloid leukemia. In: Steven $H$, Harris N, Jaffe E. WHO Classification of Tumours of Haematopoietic and Lymphoid Tissues. 4th ed. International Agency for Research on Cancer (IARC); 2017. $130 \mathrm{p}$.

5. Al-Kzayer LF, Uyen LT, Al-Jadiry MF, Al-Hadad SA, AlBadri SA, Ghali HH, Ameen NA, Liu T, Matsuda K, Abdulkadhim JM, Al-Shujairi TA, Matti ZI, Hasan JG, AlAbdullah HM, Al-Ani MH, Saber PA, Khalil HM, Inoshita T, Kamata M, Koike K, Sakashita K. Analysis of class I and II aberrations in Iraqi childhood acute myeloid leukemia using filter paper cards. Ann Hematol. 2014;93(6):94955. [PubMed] [Google Scholar]

6. Kassem NM, Medhat N, Kassem HA, El-Desouky MA. Chemotherapeutic resistance in Egyptian acute myeloid leukemia patients. Asian Pac J Cancer Prev. 2019;20(8):2421-7. [PubMed] [Google Scholar]

7. Klein K, Kaspers G, Harrison CJ, Beverloo HB, Reedijk A, Bongers $M$, Cloos J, Pession A, Reinhardt D, Zimmerman 
M, Creutzig U, Dworzak M, Alonzo T, Johnston D, Hirsch B, Zapotocky M, Moerloose BD, Fynn A, Lee V, Taga T, Tawa A, Auvrignon A, Zeller B, Forestier E, Salgado C, Balwierz W, Popa A, Rubnitz J, Raimondi $S$, Gibson B. Clinical impact of additional cytogenetic aberrations, CKIT and RAS mutations, and treatment elements in pediatric $t(8 ; 21)$-AML: results from an international retrospective study by the International Berlin-Frankfurt-Münster Study Group. J Clin Oncol. 2015;33(36):4247-58. [PubMed] [Google Scholar]

8. Nguyen $S$, Leblanc T, Fenaux P, Witz F, Blaise D, Pigneux $A$, Thomas $X$, Rigal-Huguet $F$, Lioure $B$, Auvrignon $A$, Fiere D, Reiffers J, Castaigne S, Leverger G, Harousseau $\mathrm{JL}$, Socie G, Dombret H. A white blood cell index as the main prognostic factor in $t(8 ; 21)$ acute myeloid leukemia $(A M L)$ : a survey of 161 cases from the French AML Intergroup. Blood. 2002;99(10):3517-23. [PubMed] [Google Scholar]

9. Gbadamosi B, Ezekwudo D, Bastola S, Jaiyesimi I. Predictive and prognostic markers in adults with acute myeloid leukemia: a single-institution experience. Clin Lymphoma Myeloma Leuk. 2018;18(7):e287-94. [PubMed] [Google Scholar]

10. Kulsoom B, Shamsi TS, Ahmed N, Hasnain SN. Clinical presentation of acute myeloid leukaemia - a decade-long institutional follow-up. J Pak Med Assoc. 2017;67(12):1837-42. [PubMed] [Google Scholar]

11. Abd MS, Alwash MM, Ahmed AA. Polymorphism of TET2 gene among Iraqi acute myeloid leukemia. Biochem Cell Arch. 2020;20(2):4571-5. [Google Scholar]

12. Padilha SL, Souza EJ, Matos MC, Domino NR. Acute myeloid leukemia: survival analysis of patients at a university hospital of Paraná. Rev Bras Hematol Hemoter. 2015;37(1):21-7. [PubMed] [Google Scholar]

13. Yun JW, Bae YK, Cho SY, Koo H, Kim HJ, Nam DH, Kim $\mathrm{SH}$, Chun S, Joo KM, Park WY. Elucidation of novel therapeutic targets for acute myeloid leukemias with RUNX1-RUNX1T1 fusion. Int J Mol Sci. 2019;20(7):1717. [PubMed] [Google Scholar]

14. Auewarakul CU, Lauhakirti D, Promsuwicha O, Munkhetvit C. C-kit receptor tyrosine kinase (CD117) expression and its positive predictive value for the diagnosis of Thai adult acute myeloid leukemia. Ann Hematol. 2006;85:108-12. [PubMed] [Google Scholar]

15. Webber BA, Cushing MM, Li S. Prognostic significance of flow cytometric immunophenotyping in acute myeloid leukemia. Int J Clin Exp Pathol. 2008;1(2):12433. [PubMed] [Google Scholar] 